In this epidemic too the clinical picture was characteristic and the course mild. The exanthem lasted for an average of nine days (2-17 days). In four cases it was possible to determine the interval between the onset in a schoolchild and in brothers or sisters at home. This was on average 23 days (7-30 days), which is nearly the same as that found in the epidemic in north Devon. The difficulties of diagnosis are illustrated by the fact that out of 10 children with the exanthem who were seen by their general practitioner, only two were diagnosed as having erythema infectiosum; four were thought to have rubella and in four cases an allergic rash was suspected.

A case history was sent with colour photographs to 20 general practitioners in the district of Funen. Out of 18 doctors who answered the questionnaire nine gave the right diagnosis, seven did not know about the disease, and two doctors thought it was some viral exanthem. Only two doctors had not seen a similar case in the past. Thus it can be concluded that a more precise diagnosis might be achieved when the characteristics of the disease are emphasised, as in the article by Drs Cramp and Armstrong. In that way unnecessary treatment will be avoided as well as exclusion from school and uncertainty in doctors and parents concerning epidemiological regulations.

Transient arthritis has been described as a complication of the disease, together with one case of haemolytic anaemia and one case of encephalitis in a boy of eight five days after the onset of erythema infectiosum. ${ }^{5}$ In the epidemic described by us no such complications were found.

F BRANDRUP P $\varnothing_{\text {LHOLM LARSEN }}$

Department of Dermatology and
Venereology,
Odense University Hospital,
Odense, Denmark

' Watts, C A H, Lancet, 1954, 1, 573 .
' Watts, C A H, British Medical fournal, 1974, 4, 466.
3 Medhurst, A W J, British Medical fournal, 1975, 1,
$\quad 394$.
' Brandrup, F $\emptyset$, and Larsen, P $\varnothing$, Ugeskrift for Laeger,
1976, 138, 737 .
s Balfour, H H, Clinical Pediatrics, 1969, 8, 721 .

\section{Quality of life}

SIR,-Dr A C D Cayley's letter on this subject (5 June, $p$ 1406) applies not only to the geriatric patient but also to the severely disabled or handicapped.

If the patients were kept at home and looked after by members of their own families it would save a lot of money and a lot of beds. This becomes a practical proposition only if the "carers" are given adequate support and regular times off. With the knowledge that should they become ill or in need of a rest the support is available to take complete charge of the patient and the house; with the knowledge that, in addition, they can rely on having a whole 24 hours off every 8-10 days; then they can face the future of caring for the patient for an indefinite period with confidence and peace of mind.

You may ask where we are going to get such paragons of virtue who are willing to work unsocial hours and be trained in the skills of heavy nursing care, pressure sore prevention, manual evacuation of bowels, catheter care etc? There is already a charitable trust that has run exactly this sort of domiciliary service for the past two years. It is called the Crossroads Care Assistant's Scheme and has been operating very successfully in the Rugby district since Spring 1974. We have had no difficulty in recruting suitable peopleapplications being around 15 people for one job on one advertisment in the local paper. The trustees consist of four people: a representative of Associated Television, who put up the money ( $\{10000)$; a doctor; a retired principal nursing officer of the DHSS (an expert on district nurse training); and a district nursing sister (who is also a practical work teacher). The expenses of administration have been some $£ 160-180$ per year and the balance of $£ 6200$ has been spent on the care attendants' wages. Over the past two years we have cared for some 28 households a year (each including one heavy nursing care case) at a cost of $£ 5$ per week per family. You must realise that sometimes in times of stress one family might require some 40 or more hours in a week, whereas another family might not require help for more than five or six hours in 6-12 months.

We have been awarded a grant from the DHSS to keep the Rugby project going to the next 2-3 years while we try to spread the service. At present we have the expertise of running this scheme and have overcome most of the snags or difficulties, which, incidentally have been insignificant, but we have not the money to open new branches. However, a working party is being formed and we hope to "take off" and spread the scheme to other areas in the not too distant future. We are hoping that the scheme will spread by contact with adjacent communities in the same manner as we have been led to believe will occur if rabies arrives and establishes itself in Britain, but with more beneficial results.

\section{R Hudson-Evans}

12 Manor Green,
Stratford-upon-Avon

\section{Danger of instant adhesives}

SIR,-I should like to add to the warnings given by $\mathrm{Dr} W \mathrm{G} C$ Strawbridge (5 June, p 1405) about instant adhesives lest any one of your readers be tempted to use them as a means of closing tissues. They do not always cause tissues to adhere; this depends on the type of tissue and on whether it is moist or dry. When adhesion occurs, however, it is not permanent as the adhesive forms a barrier preventing the two layers of tissue from making a cross-union, and the adhesive is subsequently extruded at about 14 days after being applied to the raw surface, usually with a rather unpleasant inflammatory reaction. The dangers of this are obvious, especially if significant blood vessels are involved.

Finally, might I make a plea that these adhesives be kept away from those with a practical-joke mentality as the results could sometimes be quite tragic.

G T WATtS $\underset{\text { General Hospital, }}{\text { Birmingham }}$

\section{Nitrazepam and diazepam}

SIR,-Your leading article (12 June, $p$ 1424) on "Glutethimide - an unsafe alternative to barbiturate hypnotics" is very much to be welcomed. Here in Ipswich, where we have had positive thinking on the control of the misuse of drugs prescribed by doctors, we have included glutethimide with the barbiturates (and Mandrax (diphenhydramine and methaqualone)) in our overall policy of reduction. Indeed, my partners and I have not prescribed glutethimide for many years.

Your ultimate conclusion, however, that "if doctors must prescribe hypnotics they should think twice before prescribing anything other than nitrazepam" is open to slight dispute. This is only because another, even better known benzodiazepine-diazepam-is known to be as safe and, in the opinion of many doctors including myself, is just as effective as nitrazepam, which is much more expensive. Undoubtedly it has been a marketing policy of those manufacturers producing benzodiazepines that there should be different indications for different members of the group; however, research does not really confirm that any of the group are any more effective than the most widely prescribed member, which in appropriate dosage is as effective a hypnotic as it is a tranquilliser. That being so, the conclusion that diazepam is the hypnotic of choice, if a hypnotic is to be prescribed at all, should be generally acceptable. Certainly the new edition of the British National Formulary confirms this impression.

Ipswich

F O Wells

\section{Training of medical laboratory} technicians

SIR, - It would seem that the staff requirements of many laboratories are forgotten by those (29 May, p 1339) who protest against the recent proposals by the Department of Health and Social Security that (1) only $25 \%$ of those technicians holding a Higher National Certificate should proceed to further training, and (2) the fellowship requirement for promotion to senior grades should be removed.

In many laboratories there are too many highly qualified technicians and insufficient staff for the many tasks which require simple training. This means that highly qualified staff have often to do simple tasks, which leads to boredom so that these tasks are less well done than by more junior or unqualified staff. Also, the refusal of the Institute of Medical Laboratory Sciences to accept laboratory aides is a failure to recognise the actual needs of many laboratories.

Although I appreciate the concern of technicians that their career structure should not be jeopardised, I think that a more realistic view of the staffing needs of medical laboratories would not only give more job satisfaction but also save money.

Constance A C Ross Microbiology Laboratory,
Ayrshire Central Hospital,
Irvine

Future of community medicine

SIR,-I should like to endorse many of $\mathrm{Dr}$ L M Mayer-Jones's comments (5 June, p 1406). I was one who viewed reorganisation with a mixture of trepidation and qualified optimism, hoping that the integration of the former public health medical personnel with the main stream of medicine would result in benefits for the community. It was not to be. 